\title{
Immunohistochemical Expression of Growth Hormone Secretagogue Receptor (GSH-R) of Adipose Tissue Macrophagesin Obese Bariatric Patients
}

\begin{abstract}
DANIEL TIMOFTE ${ }^{1}$, VERONICA MOCANU2*, FLORIN ZUGUN ELOAE ${ }^{3,5}$, IOANA HRISTOV ${ }^{2}$, IUSTINA SILIVESTRU CRETU², VIVIANA AURSULESEI ${ }^{4}$, GHEORGHE G. BALAN ${ }^{8}$, BOGDAN MIHNEA CIUNTU1*, TEODOR OBOROCEANU², ADRIAN TIRON ${ }^{5}$, VICTOR VLAD COSTAN ${ }^{6 *}$, DOINA BUTCOVAN ${ }^{1}$

${ }^{1}$ Grigore T. Popa University of Medicine and Pharmacy, Department of Surgery - General Surgery,16 Universitatii Str., 700115 lasi, Romania.

${ }^{2}$ Grigore T. Popa University of Medicine and Pharmacy, Department of Morpho-Functional Sciences - Pathophysiology, 16 Universitatii Str., 700115 lasi, Romania.

${ }^{3}$ Grigore T. Popa University of Medicine and Pharmacy, Department of Morpho-Functional Sciences - Immunology, 16 Universitatii Str., 700115 lasi, Romania.

${ }^{4}$ Grigore T. Popa University of Medicine and Pharmacy, Department of Internal Medicine - Cardiology, 16 Universitatii, St., 700115 Iasi, Romania;

5TRANSCEND Research Center, Regional Institute of Oncology, 2-4 G-ral Henri Mathias Berthelot Str., 700483, Iasi, Romania ${ }^{6}$ Grigore T. Popa University of Medicine and Pharmacy, Department of Oral and Maxillofacial Surgery, 16 Universitatii, St., 700115 lasi, Romania.

${ }^{7}$ Grigore T. Popa University of Medicine and Pharmacy, Department of Morpho-Functional Sciences - Pathology, 16 Universitatii, 16 Universitatii Str., 700115 Iasi, Romania.

${ }^{8}$ Grigore T. Popa University of Medicine and Pharmacy, Faculty of General Medicine, Department of Gastroenterology, 16 Universitatii, Str., 700115 lasi, Romania

Obesity is a major cause of adipose tissue (AT) inflammation. Ghrelin (GHRL), through its growth hormone secretagogue receptor (GHS-R) present on adipose tissue macrophages (ATMS), could modulate AT inflammation.
\end{abstract}

Keywords: ghrelin, growth hormone secretagogue receptor (GHS-R), adipose tissue macrophages (ATMS), obesity

Our study aims to evaluate the immunohistochemical expression of CD68and GHS-R in subcutaneous and visceral adipose tissue in normal and obese individuals. Adipocyte diameter, macrophage infiltration, and GHS-R expression in AT are associated with obesity inflammation. Obesity is a pro-inflammatory condition in which hypertrophied adipocytes and adipose tissue-resident immune cells (primarily macrophages) both contribute to a state of chronic low-grade systemic inflammation [1,2]. Excessive lipid load causes adipocyte stress, which in turn accounts for many adverse effects of obesity, particularly insulin resistance and glucose intolerance either directly by affecting the insulin signaling pathway or indirectly via stimulation of inflammatory pathways [3]. There are considerable evidence that obese adipose tissue is markedly infiltrated by adipose tissue macrophages (ATMs); these cells appear to be at the center of obesityrelated inflammation [4-6]. Once recruited, the macrophages secrete additional chemokines, which contribute to insulin resistance $[7,8]$. Ghrelin (GHRL),a gutpeptide consisting of 28 amino acids, is the endogenous ligand of a $G$ protein coupled receptor (GPCR), growth hormone secretagogue receptor la (GHS-R1a). The GHSRla mRNA is expressed in regions of the CNS, as well as in various peripheral organs including the stomach, intestine, pancreas, thyroid, adrenal gland, kidney, heart and blood vessels [9]. This ubiquitous expression of GHS-Rla mRNA suggests that GHRL/GHS-R1a system has multiple functions, including anti-inflammatory effect [10, 11]. The expression of GHS-Rla mRNA is low in adipose tissue and the concentrations of plasmatic ghrelin are lower in obese patients as compared to normal-weight controls. Little is known aboutthe relationship between ATMs and GSH-R in adipose tissue inflammation. In our study, we proposed to investigate the association between CD68and GHS-R in adipose tissue inflammation by immunohistochemical staining.

\section{Experimental part \\ Patients}

Samples of subcutaneous and visceral adipose tissues were obtained from normal weight females undergoing laparoscopic cholecystectomy ( $N=3$, age $39 \pm 8$ years) and from morbidly obese females ( $\mathrm{N}=5$, age $42 \pm 7$ years) who underwent laparoscopic sleeve gastrectomy (LSG), from 1st of J anuary to 31st of December2018.All patients gave their consent to participate in the study prior to surgery. The study adhered to the principles of the Declaration of Helsinki and was approved by the Ethics Committee of the University of Medicine and Pharmacy from lasi, Romania.

\section{Histological examination and morphometry}

Tissue samples were fixed in buffered formaldehyde and incorporated into paraffin blocks for the study of histology. Adiposity study was done by using morphometry based on usual histological stains. Morphometry was applied on 5 random high-powerfields (HPF, x400) of subcutaneous and visceral adipose tissue. We calculated the mean adipocyte diameter (MAD) of 10 adipocytes of various sizes in a tissue area of $197229 \mu \mathrm{m}^{2}$.

\section{Immunohistochemistry of CD 68 and GHS-R}

Immunohistochemical study was made for assessing the CD68 and GSH-R expression of the macrophages in 
adipose tissue samples from obese and normal-weight patients. Monoclonal mouse antihuman CD 68 antibody (Dako, IS613) was used for targeting ATMS. GHSR Polyclonal Antibody (ThermoFisher Scientific, PA5-28752, conc. 1/500) was used. PA5-28752 targets GHS-R1 in IHC $(P)$ and shows reactivity with human samples. The PA528752 immunogen is synthetic peptide corresponding to a region within amino acids 1 and 45 of Human GHS-R1.

The two IMH markers were expressed as mean percentage values, reported to adipose tissue area.

\section{Statistical analysis}

The statistical analysis was performed using IBM SPSS Statistics 21 Software. Numerical data are reported as means \pm SDand compared using Mann-Whitney test. Categorical data are reported as number (\%) and compared by the Pearson chi-square test. Statistical significance was set at $P<0.05$.

\section{Table 1}

MEAN ADIPOCYTE DIAMETER (MAD) AND IMMUNOHISTOCHEMICAL MARKERSOF MACROPHAGES INSUBCUTANEOUS AND VISCERAL ADIPOSE TISSUE SAMPLES FROM THE OBESE AND NORMAL-WEIGHT PATIENTS. THE DATA OF MAD ARE PRESENTED AS THE MEAN ( \pm STANDARD DEVIATIONS) AND MIN-MAX VALUES

\begin{tabular}{|c|c|c|c|c|c|c|}
\hline \multicolumn{2}{|l|}{ Patients } & $\begin{array}{c}\text { Mean Adipocyte Diameter } \\
\text { ( } \mu \mathrm{m})\end{array}$ & $\begin{array}{c}\text { CD68 } \\
\text { Mean No }\end{array}$ & $\begin{array}{c}\text { CD68 } \\
\%\end{array}$ & $\begin{array}{l}\text { GSH-R } \\
\text { Mean No }\end{array}$ & $\begin{array}{c}\text { GSH-R } \\
\%\end{array}$ \\
\hline \multirow{2}{*}{$\begin{array}{l}\text { Normal-weight } \\
(\mathrm{N}=3)\end{array}$} & SAT & $78.9(31.4) / 30-145$ & 5.8 & 2.8 & 4.4 & 1.4 \\
\hline & VAT & $74.3(26.1) / 28-121$ & 2.2 & 1.1 & 4.8 & 1.1 \\
\hline \multirow{2}{*}{$\begin{array}{l}\text { Obese } \\
(\mathrm{N}=5)\end{array}$} & SAT & $88.0^{\circ}(23.1) / 59-129$ & $15.2^{*}$ & $7.4^{*}$ & $14.6^{*}$ & $7.5^{*}$ \\
\hline & VAT & $93.3^{*}(19.0) / 66-118$ & $18.2^{*}$ & $9.1^{*}$ & $18.6^{*}$ & $8.2^{*}$ \\
\hline
\end{tabular}

SAT - subcutaneous adipose tissue, VAT, visceral adipose tissue.

${ }^{*}$ P values $<0.05$ when compared with normal-weight patients.
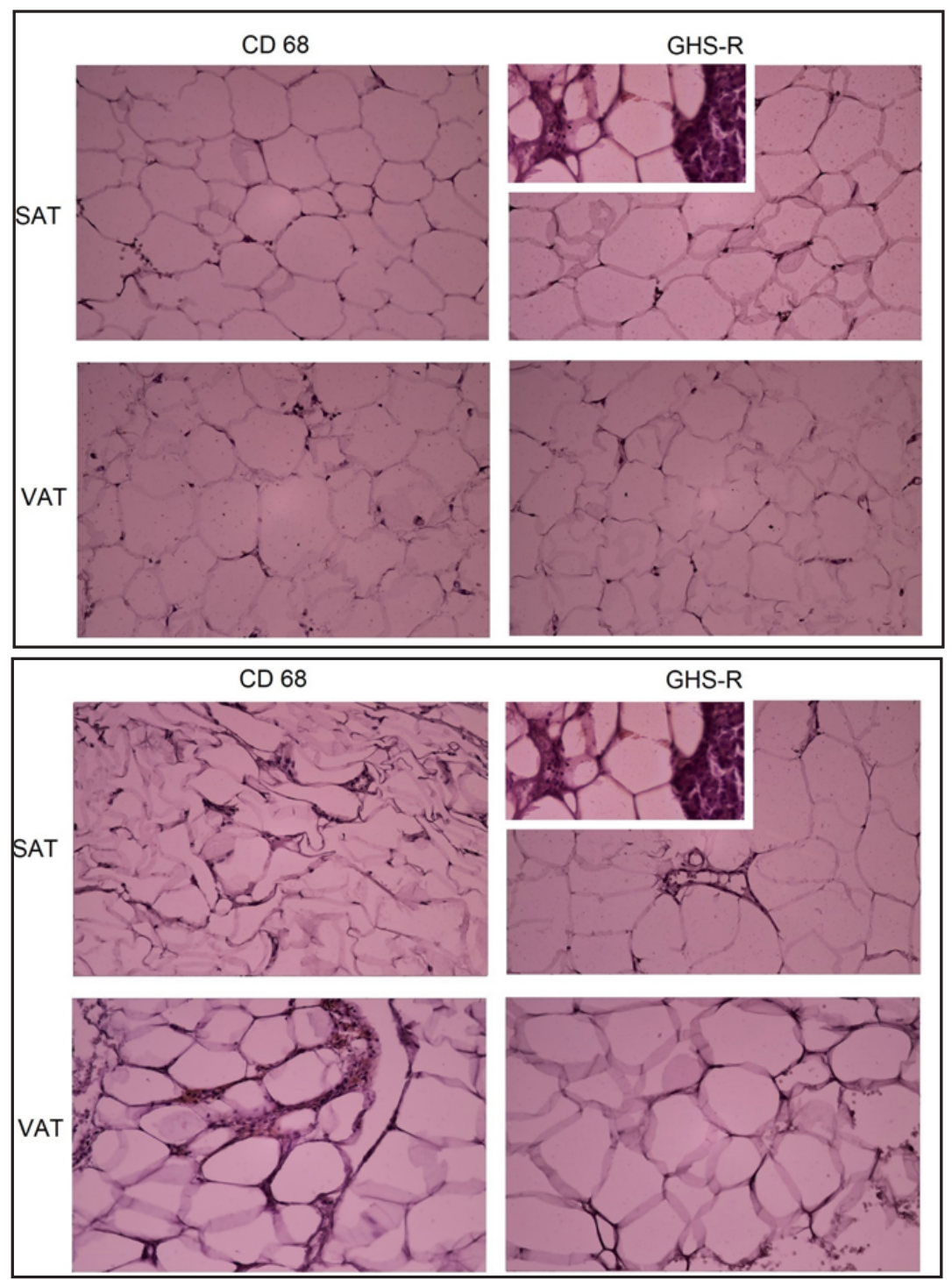

REV.CHIM.(Bucharest) $70 \diamond$ No.9 2019

http://www.revistadechimie.ro
Fig. 1. CD68 (minimal immunoreactivity) and GSH$R$ (minimal immunoreactivity) expression of macrophages in SAT and VAT from normal-weight patients. Section with fatty replacement of exocrine pancreas showing positive staining for GHS-R. Magnification 40x.

Fig. 2. CD68 (minimal immunoreactivity) and GSH-

$R$ (minimal immunoreactivity) expression of macrophages in SAT and VAT from obese patients. Section with fatty replacement of exocrine pancreas showingpositive staining for GHS-R. Magnification 40x. 
Weisberg et al. [12] observed that macrophages originating from adipose tissue represented one of the main forces in development of chronic inflammation of obesity. Adipose tissue also contribute to inflammation, secreting various hormones and cytokines which play crucial roles in obesity-associated metabolic complications [13].

Our study was focused on the relation between CD68 and GSH-R expression of ATM in adipose tissues collected from normal-weight and obese patients. We found increased CD68 immunohistochemical expression in ATs from obese patients. This finding is consistent with other research reports [14] showing increased macrophage infiltration in obese adipose tissue. The increased CD68 expression is associated with large adipose cells.

In a recent study, GHSR knockout mice fed with highfat diet (HFD) showed improved insulin sensitivity through improved adipose inflammation. Deletion of GHS-R would abolish the effect of acylghrelin and subsequently inhibit the adipose tissue inflammation, decrease the macrophage infiltration, promote the macrophages polarization to $M_{2}$ phenotype, and finally improve insulin sensitivity [15].

There is few information about the GSH-R expression in human tissues [16]. Our current data showed positive GSH-R immunohistochemical expression of ATM in obese patients. Moreover, our study showed an association between macrophage infiltration and increased GSH-R expression in adipose tissue.

Some reports noticed that, GHS-R1a ablation could promote an anti-inflammatory process under both dietinduced and age-associated adipose inflammation [17, 18]. Sun etal. also noticed that GHS-R1a deletion activates anti-inflammatory macrophages, while increased GSH-Rla is associated with inflammatory macrophages [19].

Taken together these results could suggest that ATM switch express GSH-R may have a pro-inflammatory phenotype. The immunohistochemical analysis could be a useful test to assess the macrophage functions and to predict the following development of obesity-associated metabolic complications [20-27].

\section{Conclusions}

Our study suggested that increased immunohistochemical expression of GHS-R of ATMsis associated with increased macrophage infiltration in adipose tissue. These immunohistochemical markers could be related to insulin resistance and metabolic complication in obese bariatric patients.

Acknowledgments: Research relating to this paper was funded by Grigore T. Popa University of Medicine and Pharmacy lasi, Romania, through the grants Ideas-Teams contract number 29032/28.12.2016 and number 30340/28.12.2017.

\section{References}

1.MAKKI, K., FROGUEL, P., WOLOWCZUK, I., ISRN Inflamm, 2013, 2013, No Article 139239.
2.BUTCOVAN, D., MOCANU, V., BARAN, D., CIURESCU, D., TINICA, G., Exp Ther Med, 11, no. 5, 2016, p. 2028.

3.VEGIOPOULOS, A., ROHM, M., HERZIG, S., EMBO J , 36, no. 14, 2017, p. 1999.

4.BOUTENS, L., STIENSTRA, R., Diabetologia, 59, no. 5, 2016, p. 879.

5.LESNA, I.K., CEJ KOVA, S., KRALOVA, A., FRONEK, J., PETRAS, M., et al., Nutr Diabetes, 7, no. 4, 2017, p. e264.

6.PINZARIU, A.C., PASCA, S.A., SINDILAR, A., DROCHIOI, C., BALAN, M., et al., Rev. Chim. (Bucharest), 68, no. 9, 2017, p. 2139.

7.FRANCESCHI, C., BONAFE, M., VALENSIN, S., OLIVIERI, F., DE LUCA, M., et al., Ann N Y Acad Sci, 908, 2000, p. 244.

8.WU, D., REN, Z., PAE, M., GUO, W., CUI, X., et al., J Immunol, 179, no. 7, 2007, p. 4829.

9.KITAZAWA, T., KAIYA, H., Front Endocrinol (Lausanne), 10, no., 2019, p. 278.

10.NOKHBEHSAIM, M., NOGUEIRA, A.V.B., MEMMERT, S., DAMANAKI, A., EICK, S., et al., Braz Oral Res, 33, 2019, p. e025.

11.YANAGI, S., SATO, T., KANGAWA, K., NAKAZATO, M., Cell Metab, 27, no. 4, 2018, p. 786.

12.WEISBERG, S.P., MCCANN, D., DESAI, M., ROSENBAUM, M., LEIBEL, R.L., et al., J Clin Invest, 112, no. 12, 2003, p. 1796.

13.WELLEN, K.E., HOTAMISLIGIL, G.S., J Clin Invest, 112, no. 12, 2003, p. 1785.

14.RUSSO, L., LUMENG, C.N., Immunology, 155, no. 4, 2018, p. 407. 15.YUAN, F., MA, J., XIANG, X., LAN, H., XU, Y., et al., Biomed Res Int, 2018, 2018, p. No. Article 4924325.

16.GNANAPAVAN, S., KOLA, B., BUSTIN, S.A., MORRIS, D.G., MCGEE, P., et al., J Clin Endocrinol Metab, 87, no. 6, 2002, p. 2988.

17.LI, W.G., GAVRILA, D., LIU, X., WANG, L., GUNNLAUGSSON, S., et al., Circulation, 109, no. 18, 2004, p. 2221.

18.BOULOUMIE, A., CURAT, C.A., SENGENES, C., LOLMEDE, K., MIRANVILLE, A., et al., Curr Opin Clin Nutr Metab Care, 8, no. 4, 2005, p. 347.

19.SUN, K., KUSMINSKI, C.M.. SCHERER, P.E., J Clin Invest, 121, no. 6, 2011, p. 2094.

20.UNGURIANU, S., DIMOFTE, F., NEGRU, R.D., COJOCARU, D.C., POPA, F., VINTILA, D., CIUNTU, B.M., International J ournal of Medical Dentistry, 22, no. 1, 2018, p. 30.

21.CIUNTU, B.M. , GEORGESCU, S.O., CIRDEIU, C., TIMOFTE, D., AZOICAI, D., TECUCEANU, A., MORARU, D.C., SCHAAS, C., BLAJ, M., TAMAS, C., Rev.Chim. (Bucharest), 68, no. 11, p. 2687.

22.NEAGOE, R.M., CVASCIUC, I.T., MURESAN, M., SALA, D.T., Acta Endo (BuC), 13, no. 4, 2017, p. 467.

23.CIOBICA, A., PADURARIU, M., CIOBICA, A., et al., International Journal of Geriatric Psychiatry, 32, no. 1, 2017, p. 116.

24. OCHIUZ, L., GRIGORAS, C., POPA, M., et al., Molecules, 21, no. 7, 2016, p. 858.

25.ARCAN, O., BILD, W., CIOBICA, A., et al., Romanian Biotechnological Letters, 19, no. 5, 2014,p. 9763.

26. GRADINARU, I., TIMOFTE, D., VASINCU, D., et al., Mat. Plast., 51, no. 3, 2014, p. 230.

27. NEAGOE, R.M., MURESAN, M., BANCU, S., et al., Obesity Surg., 27, no. 4, 2016, p. 983.

Manuscript received: 8.04 .2019 